\title{
UJI AKTIVITAS ANTIBAKTERI EKSTRAK RIMPANG LENGKUAS MERAH (Alpinia purpurata K. Schum) TERHADAP BAKTERI Klebsiella pneumonia ISOLAT URIN PADA PENDERITA INFEKSI SALURAN KEMIH
}

\author{
Novanda Sulistio Puasa ${ }^{1)}$, Fatimawali ${ }^{1)}$, Weny I Wiyono ${ }^{1)}$ \\ ${ }^{1)}$ Program Studi Farmasi FMIPA UNSRAT Manado, 95115
}

\begin{abstract}
Red galangal rhizome is a plant that has various properties including as an antibacterial and antifungal. Red galangal rhizome in addition to containing essential oils also contains flavonoid, phenol and terpenoid compounds. Red galangal is also used as a basic ingredient of modern medicine. The content of flavonoid compounds which are thought to inhibit the growth of bacteria. This study aims to determine the antibacterial activity of red galangal rhizome extract (Alpinia purpurata K.Schum) against the growth of Klebsiella pneumoniae bacteria of urine isolates in urinary tract infections patients. Red galangal rhizome plants were extracted by maceration method using 96\% ethanol solvent. Antibacterial activity test was carried out using the disc and wells method. The results showed that the red galangal rhizome extract has antibacterial activity against the bacteria Klebsiella pneumoniae. In the disc method for concentrations of $80 \%, 60 \%, 40 \%, 20 \%$ and $10 \%$ the average diameter of the clear zone is 13 $\mathrm{mm}, 12.3 \mathrm{~mm}, 10.6 \mathrm{~mm}, 10.5 \mathrm{~mm}$ and $9.8 \mathrm{~mm}$. The ability of antibacterial activity is included in the strong category because it has an inhibition of 10-20 mm. In the method of wells the average diameter of the clear zone is $15.6 \mathrm{~mm}, 14.6 \mathrm{~mm}, 13.6 \mathrm{~mm}, 13 \mathrm{~mm}$ and $11.3 \mathrm{~mm}$. The ability of antibacterial activity in the well method of concentrations of $80 \%, 60 \%, 40 \%, 20 \%$ and $10 \%$ is included in the strong category because the average diameter of inhibition is 10-20 $\mathrm{mm}$.
\end{abstract}

Keywords: Alpinia purpurata K. Schum, Klebsiella pneumoniae, Red Galangal Rhizome

\begin{abstract}
ABSTRAK
Rimpang Lengkuas merah merupakan tanaman yang memiliki berbagai khasiat di antaranya sebagai antibakteri dan antijamur. Rimpang Lengkuas merah selain mengandung minyak atsiri juga mengandung golongan senyawa flavonoid, fenol dan terpenoid. Lengkuas Merah juga digunakan sebagai bahan dasar obat-obatan moderen. Kandungan senyawa flavonoid yang diduga dapat menghambat pertumbuhan bakteri yang telah resisten antibiotik. Penelitian ini bertujuan untuk mengetahui aktivitas antibakteri ekstrak rimpang Lengkuas merah (Alpinia purpurata K.Schum) terhadap pertumbuhan bakteri Klebsiella pneumoniae isolat urin pada penderita infeksi saluran kemih. Tanaman rimpang Lengkuas merah di ekstraksi dengan metode maserasi menggunakan pelarut etanol 96\%. Uji aktivitas antibakteri dilakukan dengan metode cakram dan sumuran. Hasil penelitian menunjukkan bahwa ekstrak rimpang Lengkuas merah memiliki aktivitas antibakteri terhadap bakteri Klebsiella pneumoniae. Pada metode cakram untuk konsentrasi $80 \%, 60 \%, 40 \%, 20 \%$ dan $10 \%$ rata-rata diameter zona beningnya $13 \mathrm{~mm}$, $12,3 \mathrm{~mm}, 10,6 \mathrm{~mm}, 10,5 \mathrm{~mm}$ dan $9,8 \mathrm{~mm}$. Kemampuan aktivitas antibakteri termasuk dalam kategori kuat karena memiliki daya hambat $10-20 \mathrm{~mm}$. Pada metode sumuran rata-rata diameter zona beningnya ialah 15,6 mm, 14,6 mm, 13,6 mm, $13 \mathrm{~mm}$ dan 11,3 mm. Kemampuan aktivitas antibakteri pada metode sumuran konsentrasi $80 \%, 60 \%$, 40\%, $20 \%$ dan $10 \%$ termasuk dalam kategori kuat karena rata-rata diameter daya hambatnya $10-20 \mathrm{~mm}$.
\end{abstract}

Kata kunci : Rimpang Lengkuas merah, Alpinia purpurata K.Schum, Klebsiella pneumoniae 


\section{PENDAHULUAN}

Penyakit infeksi merupakan jenis penyakit yang paling banyak diderita oleh penduduk di negara berkembang, termasuk Indonesia. Salah satu penyebab penyakit infeksi ialah mikroorganisme bakteri (Radji, 2011). Infeksi saluran kemih disebabkan oleh invasi mikroorganisme naik dariuretra ke dalam kandung kemih. Invasi mikroorganisme dapat mencapai ginjaldipermudah dengan refluks vesikoureter (Liza, 2006).

Penyakit infeksi merupakan salah satu masalah dalam dunia kesehatan (Rambiko, 2016) Menurut National Kidney and Urologic Diseases Information Clearinghouse (2011), infeksi saluran kemih (ISK) merupakan jenis infeksi kedua yang paling umum terjadi di dalam tubuh. Di Indonesia, tercatat sekitar 150 juta penduduk di dunia tiap tahunnya terdiagnosis menderita ISK (Rajabnia et al., 2012). Penderita rawat darurat penyakit ISK di Manado pada tahun 2016 tercatat sebanyak 191 penderita dalam sepuluh jenis penyakit terbanyak di RSUP Manado (BPS SULUT, 2017). Akhirakhir ini sudah banyak antibiotik yang resisten terhadap bakteri. Sebagai alternatif, saat ini ada banyak tanaman yang dapat digunakan sebagai obat tradisional untuk mengobati berbagai penyakit, karena banyak orang beranggapan bahwa penggunaan obat tradisional relatif lebih aman dibandingkan dengan obat yang berasal dari bahan kimia (Eka, 2013). Keanekaragaman hayati yang memiliki potensi untuk dikembangkan sebagai obat tradisional untuk mengatasi ISK ialah Lengkuas merah (Alpinia purpurata K.Schum). Rimpang Lengkuas merah selain mengandung minyak atsiri juga mengandung golongan senyawa flavonoid, fenol dan terpenoid. Rimpang Lengkuas memiliki kandungan senyawa flavonoid yang diduga mampu menghambat pertumbuhan bakteri yang telah resisten terhadap antibiotik (Yuharmen, 2002).

Antibiotik yang saat ini masih banyak digunakan dalam klinis untuk pengobatan ISK adalah Ciprofloxacin. Ciprofloxacin merupakan golongan flouroquinolone yang mempunyai daya hambat bakteri lebih kuat dan spektrum Ciprofloxacin memiliki aktivitas yang sangat luas, baik terhadap bakteri Gram-positif maupun Gram-negatif (Delign, 2004).

Menurut penelitian Poetry (2018), Lengkuas merah memiliki daya hambat terhadap bakteri Klebsiella pneumoniae menggunakan konsentrasi 100\% 75\%, 50\% 25\% dan $12,5 \%$ yang diisolat dari sputum pada penderita pneumonia resisten antibiotik Seftriakson. Berdasarkan latar belakang diatas, peneliti tertarik untuk meneliti uji aktivitas antibakteri eksrak rimpang lengkuas merah (Alpinia purpurataK.Schum) dengan menggunakan isolat urin penderita infeksi saluran kemih.

\section{METODOLOGI PENELITIAN}

\section{Waktu dan Tempat Penelitian}

Penelitian ini akan dilakukan pada bulan Juni 2019 - September 2019 di laboratorium Farmasi Lanjutan 
Program Studi Farmasi Fakultas Matematika dan Ilmu Pengetahuan Alam Universitas Sam Ratulangi Manado.

\section{Alat dan Bahan}

Alat

Alat yang digunakan yaitu timbangan analitik (aeADAM $\AA)$, blender (Philips $\AA)$, oven, lemari pendingin, gelas ukur (Pyrex $\left.{ }^{\circledR}\right)$, tabung reaksi(Pyrex $\left.{ }^{\circledR}\right)$, Erlenmeyer (Pyrex $\left.{ }^{\circledR}\right)$, beker gelas (Pyrex $\AA)$, corong, batang pengaduk, cawan petri (Pyrex®), kertas saring,, jarum ose, pencadang, pingset, mikropipet (ecopippetteTM), laminar air flaw(N-Bioteckß), autoklav (ALP®), incubator (MMM Group $\left.{ }^{\circledR}\right)$, aluminium foil, Hot plate(NESCO®Lab), penyebar sel bentuk L, jangka sorong, BCC, kertas lebel dan spritus.

\section{Bahan}

Bahan yang digunakan dalam penelitian ini yaitu bakteri Klebsiella pneumoniae yang resisten antibiotik Ciprofloxacin ekstrak rimpang Lengkuas merah, etanol $96 \%$, aquades, media nutrient agar (NA), Ciprofloxacin tablet, Ciprofloxacin Antimicrobial Susceptibility Disks $5 \mu \mathrm{g}$, kertas cakram, $\mathrm{NaCl} \quad 0,9 \%, \quad \mathrm{H} 2 \mathrm{SO} 4 \quad 0,36 \mathrm{~N}$ dan $\mathrm{BaCl} 2.2 \mathrm{H} 2 \mathrm{O} 1,175 \%$, CMC Jenis penelitian ini merupakan eksperimental laboratorium dengan sampel ekstrak etanol tanaman rimpang Lengkuas merah yang dibuat dengan lima variasi konsentrasi $80 \%, 60 \%, 40 \%, 20 \%$ dan $10 \%$ dan dilakukan pengujian pada bakteri uji.

\section{Persiapan Sampel}

Sampel yang digunakan diambil dari pasar Desa Kolongan Tetempangan, Kecamatan Kalawat, Kabupaten Minahasa Utara, Sulawesi Utara. Sampel yang diambil ialah bagian rimpang Lengkuas merah yang masih segar.Pada tahap awal sampel rimpang Lengkuas merah ditimbang dengan berat $2 \mathrm{~kg}$. Selanjutnya dicuci dengan air mengalir dengan tujuan menghilangkan pengotor. Sampel kemudian dirajang untuk mempermudah proses pengeringan. Pengeringan sampel dilakukan dengan cara diangin-anginkan selama 1 minggu. Sampel yang sudah kering kemudian di blender hingga menjadi serbuk dan ditimbang. Serbuk yang dihasilkan diayak dengan ayakan mesh, hingga diperoleh serbuk halus.

\section{Pembuatan Ekstrak}

Metode yang digunakan untuk mengekstrak rimpang Lengkuas merah (Alpinia purpurata K.Schum), yaitu dengan menggunakan metode maserasi. Ditimbang sebanyak $150 \mathrm{~g}$, kemudian dimasukkan ke wadah tertutup rapat. Sampel yang telah ditimbang diekstraksi dengan $750 \mathrm{~mL}$ etanol $96 \%$ pada suhu kamar selama 7 hari sambil sesekali diaduk. Setelah 7 hari sampel disaring dengan menggunakan kertas saring menghasilkan filtrat satu. Sisanya dimaserasi kembali dengan $450 \mathrm{~mL}$ pelarut etanol $96 \%$ selama 2 hari sambil sesekali diaduk kemudian di saring dengan kertas saring menghasilkan filtrat dua. Filtrat satu 
dan filtrat dua dikumpulkan dan diuapkan menggunakan oven, sehingga diperoleh ekstrak kental Lengkuas merah dengan konsentrasi $100 \%$.

\section{Sterilisasi Alat}

Sterilisasi alat dilakukan sebelum semua peralatan di gunakan, yaitu dengan cara membungkus semua peralatan dengan aluminium foil kemudian dimasukkan kedalam autoklaf untuk sterilisasi dengan suhu 1210C selama 15 menit.

\section{Pembuatan Media Dasar dan Media Pembenihan}

Diambil Nutrient Agar (NA) sebanyak 5,6 gram dilarutkan dalam 200 $\mathrm{mL}$ aquadest menggunakan erlenmeyer. Setelah itu, media dihomogenkan dengan stirer diatas penangas air sampai mendidih.Media yang sudah homogen ini disterilkan dalam autoklaf pada suhu 1210 C selama 15 menit, kemudian didinginkan sampai suhu \pm 45-500 C. Media dasar dan media pembenihan digunakan dalam pembuatan media pengujian sebagai lapisan dasar dan lapisan kedua.

\section{Regenerasi Bakteri}

Bakteri Klebsiella pneumoniae yang akan diujikan, terlebih dahulu harus diregenerasikan. Hal pertama yang dilakukan yaitu membuat media miring nutrien agar (NA). Media (NA) dituangkan kedalam tabung reaksi, kemudian diletakkan pada posisi miring dan didiamkan hingga agar memadat. Selanjutnya menggoreskan biakan dari stok bakteri ke agar miring nutrient agar (NA). kultur bakteri pada masing- masing agar miring diinkubasi pada suhu 370C selam 18-24 jam.

\section{Pembuatan Larutan Mc.Farland 0,5}

Larutan $\mathrm{H} 2 \mathrm{SO} 4$ 1\% sebanyak 9,95 mL dicampurkan dengan larutan $\mathrm{BaCl} 2$.2H2O 1,175\% sebanyak 0,05 $\mathrm{mL}$ dalam erlenmeyer. Kemudian dikocok sampai terbentuk larutan yang keruh. Kekeruhan ini dipakai sebagai standar kekeruhan suspensi bakteri uji (Borges dan Bresson, 2004).

\section{Suspensi Bakteri}

Suspensi bakteri dilakukan dengan cara bakteri uji yang telah diregenerasi diambil dengan jarum ose lalu disuspensikan ke dalam tabung reaksi berisi $5 \mathrm{~mL}$ larutan $\mathrm{NaCl}$ steril $0,9 \%$. Suspensi yang terbentuk disetarakan kekeruhannya dengan larutan standar Mc farland No.0,5 yaitu 1,5 x $108 \mathrm{CFU} / \mathrm{mL}$.

\section{Pembuatan Larutan}

\section{a. Larutan Stok}

Larutan stok dibuat dari hasil ekstraksi yang diperoleh dengan konsentrasi $100 \% \quad$ kemudian diencerkan dengan CMCmendapatkan konsentrasi $80 \%$ kemudian diencerkan sebanyak empat kali pengenceran dengan masing-masing konsentrasi $60 \%, 40 \%$, $20 \%$ dan $10 \%$ dengan menggunakan rumus :

$$
\mathrm{M} 1 \mathrm{~V} 1=\mathrm{M} 2 \mathrm{~V} 2
$$

\section{b. Larutan Kontrol Positif dan Kontrol Negatik}

Kontrol positif dibuat dari sediaan obat tablet ciprofloxacin 500 
mg, dengan cara satu tablet ciprofloxacin digerus. Setelah itu di timbang $65 \mathrm{mg}$ dan dilarutkan dalam 50 $\mathrm{mL}$ aquadest, selanjutnya dibuat dengan cara diambil $1 \mathrm{~mL}$ larutan dan ditambahkan aquadest hingga $10 \mathrm{~mL}$ untuk memperoleh larutan ciprofloxacin $5 \mu \mathrm{g} / 50 \mu \mathrm{L}$. Larutan kontrol negatif digunakan CMC.

\section{Uji Aktivitas}

\section{a. Metode Cakram}

Media Nutrien Agar (NA) sebanyak $15 \mathrm{~mL}$ dituang ke dalam cawan petri dan dibiarkan memadat, kemudiaan dimasukkan $1 \mathrm{~mL}$ suspensi bakteri Klebsiella pneumoniae yang telah dicampurkan ke dalam media pembenihan NA kemudian disebarkan biakan bakteri dengan menggunakan pipa bentuk L agar suspensi tersebar merata pada media dan didiamkan selama 10 menit agar suspensi terserap pada media.Cawan petri tersebut diletakkan kertas cakram ukuran $6 \mathrm{~mm}$ dengan menggunakan pinset steril yang telah direndam dalam CMC (Kontrol negatif) dan kertas cakram ukuran $6 \mathrm{~mm}$ yang telah direndam dalam larutan uji. Selanjutnya semua media diinkubasi kedalam inkubator, inkubasi dilakukan pada suhu 370C selama 24 jam. Diukur diameter zona bening yang terbentuk dengan menggunakan jangka sorong.

\section{b. Metode Sumuran}

Media uji dibuat dengan dengan 2 lapisan media agar, yang pengerjaannya seperti berikut :

1.Lapisan dasar dibuat dengan menuangkan masing-masing $15 \mathrm{~mL}$ NA ke masing-masing 3 cawan petri, kemudian dibiarkan memadat.

2.Setelah memadat, permukaan lapisan dasar ditanam 5 pencadang baja yang diatur jaraknya agar daerah pengamatan tidak bertumpu.

3.Suspensi bakteri dicampurkan kedalam media pembenihan NA.

4.Selanjutkan dituangkan $15 \mathrm{~mL}$ NA pada tiap cawan petri yang diletakan pencadang sebagai lapisan kedua.

5.Setelah lapisan kedua memadat, pencadang diangkat secara aseptik menggunakan pinset dari masingmasing cawan petri, sehingga terbentuk sumur-sumur yang akan digunakan dalam uji bakteri.

6.Sumuran yang terbentuk diisi dengan larutan kontrol dan larutan uji masing-masing $50 \mu 1$.

7.Selanjutnyasemua media di inkubasi dalam inkubator pada suhu 370C selama 24 jam.

\section{Pengukuran dan Penetapan Zona Hambat}

Pengamatan dilakukan setelah 1x24 jam masa inkubasi. Zona bening merupakan petunjuk kepekaan mikroba terhadap bahan antimikroba yang digunakan sebagai bahan uji yang dinyatakan dengan lebar diameter zona hambat (Vandepite, 2005). Diameter zona hambat diukur kemudian dikategorikan kekuatan daya antibakterinya berdasarkan penggolongan Davis dan Stout (1971). 


\section{HASIL DAN PEMBAHASAN \\ Ekstraksi}

Sampel basah rimpang Lengkuas merah diperoleh sebanyak $1,5 \mathrm{~kg}$, dikeringkan dan diblender menghasilkan serbuk simplisia sebanyak 150 gram dan di ekstrak menggunakan cara maserasi.

Proses maserasi dilakukan selama 5 hari dengan menggunakan etanol $96 \%$ sebanyak $750 \mathrm{~mL}$ dan remaserasi selama 2 hari menggunakan etanol 96\% $450 \mathrm{~mL}$ hingga diperoleh hasil maserat etanol Lengkuas merah (filtrat $1+$ filtrat 2) sebanyak $1100 \mathrm{~mL}$.

Hasil maserat Lengkuas merah ini kemudian diuapkan dengan menggunakan oven dengan tujuan menguapkan etanol dari proses maserasi dan menghasilkan ekstrak kental sebayak 7,7 gram.

\section{Uji Aktifitas}

Metode Cakram

Tabel 1. Hasil Pengukuran Daya Hambat dengan Metode Cakram

\begin{tabular}{lllll}
\hline $\begin{array}{l}\text { Perlak } \\
\text { uan }\end{array}$ & U1 & U2 & U3 & $\begin{array}{l}\text { Rata- } \\
\text { rata }\end{array}$ \\
\hline $\mathrm{K}(-)$ & 0 & 0 & 0 & 0 \\
$\mathrm{~K}(+)$ & 16 & 15 & 16 & 15,6 \\
$80 \%$ & 14 & 13 & 12 & 13 \\
$60 \%$ & 12 & 13 & 12 & 12,3 \\
$40 \%$ & 11 & 10 & 11 & 10,6 \\
$20 \%$ & 10 & 11 & 10,5 & 10,5 \\
$10 \%$ & 14 & 7,5 & 8 & 9,8 \\
\hline
\end{tabular}

Metode Sumuran

Tabel 2. Hasil Pengukuran Daya Hambat dengan Metode Sumuran

\begin{tabular}{lllll}
\hline $\begin{array}{l}\text { Perlak } \\
\text { uan }\end{array}$ & U1 & U2 & U3 & $\begin{array}{l}\text { Rata- } \\
\text { rata }\end{array}$ \\
\hline $\mathrm{K}(-)$ & 0 & 0 & 0 & 0 \\
$\mathrm{~K}(+)$ & 40 & 50 & 38 & 42 \\
$80 \%$ & 14 & 15 & 18 & 15,6 \\
$60 \%$ & 13 & 15 & 17 & 14,6 \\
$40 \%$ & 13 & 13 & 15 & 13,6 \\
$20 \%$ & 10 & 10 & 19 & 13 \\
$10 \%$ & 10 & 11 & 13 & 11,3 \\
\end{tabular}

Uji daya hambat ekstrak Lengkuas merah terhadap bakteri Klebsiellapneumoniae menggunakan metode cakramdan metode sumuran. Kedua metode ini menggunakan media Nutrient Agar (NA). Media Nutrient Agar (NA) merupakan medium yang baik sebagai tempat tumbuhnya beberapa bakteri gram positif dan gram negatif yang di manfaatkan sebagai sumber nutrisi bagi pertumbuhan bakteri. Dalam uji effektivitas hasil

diperoleh melalui pengamatan yang dilakukan selama 1 x 24 jam masa inkubasi pada suhu 370C dengan 3 kali pengulangan. Pengujian ini menggunakan kontrol positif dan kontrol negatif. Kontrol positif berfungsi sebagai kontrol dari zat uji dengan membandingkan diameter daerah hambat yang terbentuk (Dwijendra, 2014). Kontrol positif yang digunakan antibiotik ciprofloxacin. Menurut Sarro (2001), antibiotik Ciprofloxacin merupakan antibiotik dengan kegiatan luas, yaitu antibiotik yang memiliki aktivitas 
banyak jenis bakteri, virus, jamur dan protozoa. Kontrol negatif berfungsi untuk mengetahui ada tidaknya pengaruh pelarut terhadap pertumbuhan bakteri uji Klebsiellapneumoniae, sehingga dapat diketahuibahwa yang mempunyai aktivitas antibakteri adalah zat uji bukan pelarut (Dwijendra, 2014).

Kontrol negatif yang digunakan adalah CMC.

Dari hasil yang dilakukan untuk metode difusi cakram menunjukan diameter zona hambat dari kontrol positif bakteri uji lebih besar dibandingan dengan ekstrak dan kontrol negatif yaitu 15,6 mm sedangkan untuk metode sumuran yaitu $42 \mathrm{~mm}$. Untuk kontrol negatif baik untuk metode cakram maupun metode sumuran tidak memperlihatkan adanya daya hambat untuk bakteri uji. Hal ini mengindikasikan bahwa kontrol yang digunakan tidak berpengaruh pada uji antibakteri, sehingga daya hambat yang terbentuk tidak dipengaruhi oleh pelarut melainkan karena aktivitas senyawa yang ada pada rimpang Lengkuas merah. Untuk larutan uji konsentrasi 80\%, 60\%, $40 \%$, $20 \%$ dan $10 \%$ pada metode cakram rata-rata diameter zona beningnya $13 \mathrm{~mm}, 12,3 \mathrm{~mm}, 10,6 \mathrm{~mm}$, $10,5 \mathrm{~mm}$ dan $9,8 \mathrm{~mm}$. Sedangkan pada metode sumuran rata-rata diameter zona beningnya ialah $15,6 \mathrm{~mm}, 14,6 \mathrm{~mm}$, 13,6 mm, $13 \mathrm{~mm}$ dan $11,3 \mathrm{~mm}$. Hal ini menunjukkan semakin besar konsentrasi ekstrak rimpang Lengkuas merah yang diberikan, maka semakin besar pula diameter zona bening yang terbentuk.

Maka aktivitas antibakteri ekstrak rimpang Lengkuas merah terhadap bakteri Klebsiella pneumoniaeuntuk metode cakram dengan konsentrasi 80\%, 60\%, 40\%, $20 \%$ dan $10 \%$ termasuk dalam kategori kuat karena memiliki daya hambat $10-20 \mathrm{~mm}$. Begitu juga pada metode sumuran konsentrasi $80 \%$, $60 \%, 40 \%, 20 \%$ dan $10 \%$ termasuk dalam kategori kuat karena rata-rata diameter daya hambatnya $10-20 \mathrm{~mm}$.

Pada Pada penelitian ini metode sumuran menunjukkan hasil yang lebih baik yaitu zona hambat yang terbentuk lebih besar dibandingkan metode cakram. Hal ini terjadi karena banyak faktor dan teori, pada metode sumuran ekstrak langsung di masukkan ke setiap lubang, sehingga efek untuk menghambat bakteri menjadi lebih kuat. Sedangkan pada metode cakram, kertas cakram harus di rendam dalam larutan ekstrak Lengkuas lalu diletakkan di atas media NA. Hasil dari penelitian ini sesuai dengan penelitian yang telah dilakukan Eka (2013), yang menyatakan bahwa dengan menggunakan metode sumuran dapat menghasilkan diameter zona hambat yang besar. Dan diperkuat dalam penelitian Eka (2013), Hal ini terjadi karena pada metode sumuran terjadi proses osmolaritas dari konsentrasi ekstrak yang lebih tinggi dari metode cakram.

Pada metode sumuran setiap lubang di isi dengan konsentrasi ekstrak, maka osmolaritas terjadi lebih menyeluruh dan lebih homogen serta konsentrasi ekstrak yang dihasilkan lebih tinggi dan lebih kuat untuk menghambat pertumbuhan bakteri. Terbentuknya daerah zona hambat 
menunjukkan terjadinya penghambatan pertumbuhan koloni bakteri yang diduga akibat pengaruh senyawa bioaktif yang terdapat pada ekstrak Lengkuas merah. Menurut penelitian Herbi (2015)yang melakukan skrining fitokimia Lengkuas merah dan Lengkuas putih, menunjukkan hasil untuk ekstrak etanolrimpang Lengkuas merah positif mengandung golongan senyawa flavonoid, tannin, kuinon dan terpenoid. Selain itu ekstrak rimpang Lengkuas merah juga mengandung minyak atsiri seperti yang diungkapkan Kunia (2007), senyawa-senyawa tersebut diduga merupakan senyawa yang berperan dalam menghambat pertumbuhan bakteri Klebsiella pneumoniae.

Menurut Victorio et al (2009), rimpang lengkuas mengandung minyak atsiri yang terdiri dari metilsinamat, sineol, kamfer, galangin, dan eugenol. Dapat menghambat pertumbuhan atau mematikan bakteri dengan mengganggu proses terbentuknya membran atau dinding sel karena komponen struktural membran sel bakteri tersusun atas protein dan lipid, hal ini menyebabkan membran sel rentan terhadap zat kimia yang dapat menurunkan tegangan permukaan. Kerusakan membran sel menyebabkan terganggunya transport nutrisi (senyawa dan ion) melalui membran sel yang pada akhirnya dapat menyebabkan gangguan terhadap pertumbuhan bakteri.

Menurut Ajizah (2004), diduga menjadi penyebab gangguan terhadap pertumbuhan Klebsiella pneumoniae karena adanya efek fenolik dari flavonoid. Senyawa fenol dapat bersifat koagulator protein. Protein yang menggumpal tidak dapat berfungsi lagi, sehingga akan mengganggu pembentukan dinding sel bakteri sehingga pada akhirnya bakteri kehilangan kemampuan membentuk kolono dan menyebabkan kematian sel.

\section{KESIMPULAN}

Hasil penelitian yang dilakukan dapat disimpulkan bahwa ekstrak rimpang Lengkuas merah memilikiaktivitas antibakteri terhadap bakteri Klebsiella pneumoniae yang resisten antibiotik ciprofloxacin. Untuk metode cakram dan sumuran konsentrasi $80 \%, 60 \%, 40 \%, 20 \%$ dan $10 \%$ sama-sama termasuk kategori kuat.

\section{SARAN}

Perlu dilakukan penelitian lebih lanjut tentang potensi antibakteri dari zat aktif yang terdapat dalam ekstrak rimpang Lengkuas merah.

\section{DAFTAR PUSTAKA}

Ajizah A, 2004. Sensitivitas Salmonella typhimurium

Terhadap Ekstrak Daun Psidum guajava L. Jurnal Bioscientiae. (1):31-38

Borges, M.T., and Bresson, W. 2004. Delivery Methods for Introducing Endophitic Bacteria into Maize. Biocontrol. 49:315-322.

Badan Pusat Statistik Sulawesi Utara. 2017. Sulawesi Utara dalam angka. BPS SULUT, Manado.

Deglin, J. H. 2004. Pedoman Obat Untuk Perawat Edisi 4. Ahli Bahasa: H.Y Kuncara. EGC : Jakarta (Hal 206:240). 
Dwijendra, I. M. 2014. Aktivitas Antibakteri dan Karakterisasi Senyawa Fraksi SposLamellodysidea herbacea yang Diperoleh dari Teluk Manado [skripsi]. Program Studi Farmasi FMIPA Universitas Sam Ratulangi, Manado.

Eka, P. 2013. Perbandingan Efek Ekstrak Daun Sirih Hijau (Piper betle L.) Dengan Metode Difusi Disk dan Sumuran Terhadap Pertumbuhan Bakteri staphylococcus aureus. [SKRIPSI]. Program Studi Pendidikan Dokter Fakultas Kedokteran dan Ilmu Kesehatan Universitas Islam Negeri Syarif Hidayatullah, Jakarta.

Herbi T. 2015. KITAB Tanaman Berkhasiat Obat 226 Tumbuhan Obat Untuk Penyembuhan Penyakit dan Kebugaran Tubuh. Octpus Publishing House. Yogyakarta.

Kunia, K. 2007. Lengkuas Pengganti Formula.http://anekaplanta.word press.com/author/plantus/ Agustus 2019)

Liza. 2006. Buku Saku Ilmu Penyakit Dalam. Edisi I. FK UI : Jakarta.

National Kidney and Urologic Diseases Information Clearinghouse. 2011.Urinary Tract Infections in Adults. U.S. Department of Health and Human Services.

Poetry, 2018. Uji Daya Hambat Ekstrak Rimpang Lengkuas Merah (Alpinia purpurata K.Schum) Terhadap Pertumbuhan Bakteri Klebsiella pneumoniae Isolat Sputum Pada Penderita Pneumonia Resisten Antibiotik Seftriakson.Skripsi.Fakultas Matematika dan Ilmu Pengetahuan Alam : Universitas Sam Ratulangi,Manado.

Radji, M., 2011. Mikrobiologi
Panduan Mahasiswa Farmasi dan Kedokteran. PenerbitBuku Kedokteran EGC, Jakarta.

Rajabnia, C. M., G., S., F., F., D., A. 2012. Antibiotic Resistance Pattern in Urinary Tract Infection in Imam-Ali Hospital. Zahedan. J.Res. Med.Sci.

Rambiko, C. S., Fatimawali., Bodhi, W. 2016. Uji sensitivitas bakteri penyebab Infeksi nosokomial Saluran kemih Akibat Penggunaan Kateter Terhadap Antibiotic Ampicillin, Amoxicillin dan Ciprofloxacin diRSUP Prof.dr.R.D.Kandou Manado. Jurnal Ilmiah Farmasi Pharmacon. 5(1): 1-7.

Sarro, A.D., G.D. 2001. Adverse Reactions to Fluoroquinolones. An Overview on Mechanism Aspect. Current Medicinal Chemistry. $8: 371-384$.

Vandepitte, S. 2005. Prosedur Laboratorium Dasar untuk Bakteriologis Klinis. Edisi 2. Buku Kedokteran EGC, Jakarta.

Victorio, C.P., R.M. Kuster, and C.L.S. Lage. 2009. Detection of Flavonoids inAlpinia Purpurata (Vieil) Schum. Leaves Using High Performance

Liquchromatography. Rev. Bras. Pl. Med. Botuca(2):147153.

Yuharmen, Eryanti, dan Nurbalatif. 2002. Uji Aktivitas Antimikroba Minyak Atsiri dan Ekstrak Methanol Lengkuas (Alpiana galanga) Jurusan Kimia, Fakultas Matematika Dan lmu Pengetahuan Alam. Universitas Riau : Riau. 